See discussions, stats, and author profiles for this publication at: https://www.researchgate.net/publication/257560444

Groundwater-level trends and implications for sustainable water use in the Kabul Basin, Afghanistan

Article $\cdot$ September 2013

Dol: 10.1007/510669-013-9455-4

CITATIONS

32

3 authors, including:

Thomas J. Mack

United States Geological Survey

32 PUBLICATIONS 83 CITATIONS

SEE PROFILE
1,002

Some of the authors of this publication are also working on these related projects: 


\title{
Groundwater-level trends and implications for sustainable water use in the Kabul Basin, Afghanistan
}

\author{
Thomas J. Mack • Michael P. Chornack • \\ Mohammad R. Taher
}

Published online: 17 July 2013

(c) The Author(s) 2013. This article is published with open access at Springerlink.com

\begin{abstract}
The Kabul Basin, which includes the city of Kabul, Afghanistan, with a population of approximately 4 million, has several Afghan, United States, and international military installations that depend on groundwater resources for a potable water supply. This study examined groundwater levels in the Kabul Basin from 2004 to 2012. Groundwater levels have increased slightly in rural areas of the Kabul Basin as a result of normal precipitation after the drought of the early 2000s. However, groundwater levels have decreased in the city of Kabul due to increasing water use in an area with limited recharge. The rate of groundwater-level decrease in the city is greater for the 2008-2012 period (1.5 meters per year $(\mathrm{m} / \mathrm{yr})$ on average) than for the 2004-2008 period (0-0.7 m/yr on average). The analysis, which is corroborated by groundwater-flow modeling and a non-governmental organization decisionsupport model, identified groundwater-level decreases and associated implications for groundwater sustainability in the city of Kabul. Military installations in the city of Kabul (the Central Kabul subbasin) are likely to face water management challenges resulting from long-term groundwater sustainability concerns, such as the potential drying of shallow water-supply wells. Installations in the northern part of the Kabul Basin may have fewer issues with longterm water sustainability. Groundwater-level monitoring and groundwater-flow simulation can be valuable tools for
\end{abstract}

T. J. Mack ( $₫)$

U.S. Geological Survey, Pembroke, NH, USA

e-mail: tjmack@usgs.gov

M. P. Chornack

U.S. Geological Survey, Denver, CO, USA

M. R. Taher

Afghanistan Geological Survey, Kabul, Afghanistan assessing groundwater management options to improve the sustainability of water resources in the Kabul Basin.

Keywords Groundwater level - Groundwater depletion · Water-level network - Groundwater-flow model ·

Kabul, Afghanistan

\section{Introduction}

As of 2012, military installations in Afghanistan rely on groundwater for a significant portion of their potable water supply (Gellasch 2012). The Kabul Basin has several Afghan, United States, and international military installations including the Bagram Airfield in the north and Afghan National Army (ANA) and the International Security Assistance Force (ISAF) compounds in the city of Kabul (Fig. 1). ISAF troops in the Kabul Basin total approximately 25,000 (North Atlantic Treaty Organization 2013), and the number of Afghan troops is likely to be twice that number. Although that number is relatively small, compared to the approximately 4 million people in the Kabul Basin, water use at installations in the densely populated city of Kabul (Fig. 1) adds to existing stresses. Detailed water usage numbers at military facilities were not available to this study and may not exist for some facilities. The estimated population growth in Afghanistan from 2000 to 2010 was about $37 \%$, much greater than the high population growth rate of about $26 \%$ for other least developed countries for that same period (United Nations 2011). The Kabul Basin accounts for more than $10 \%$ of the population of Afghanistan, and people in the city and in military installations in the basin depend solely on groundwater for drinking water supplies. With a growing population and with additional water demands for potential 
Fig. 1 Population in the Kabul Basin, Afghanistan, in 2011 estimated from remotely sensed data

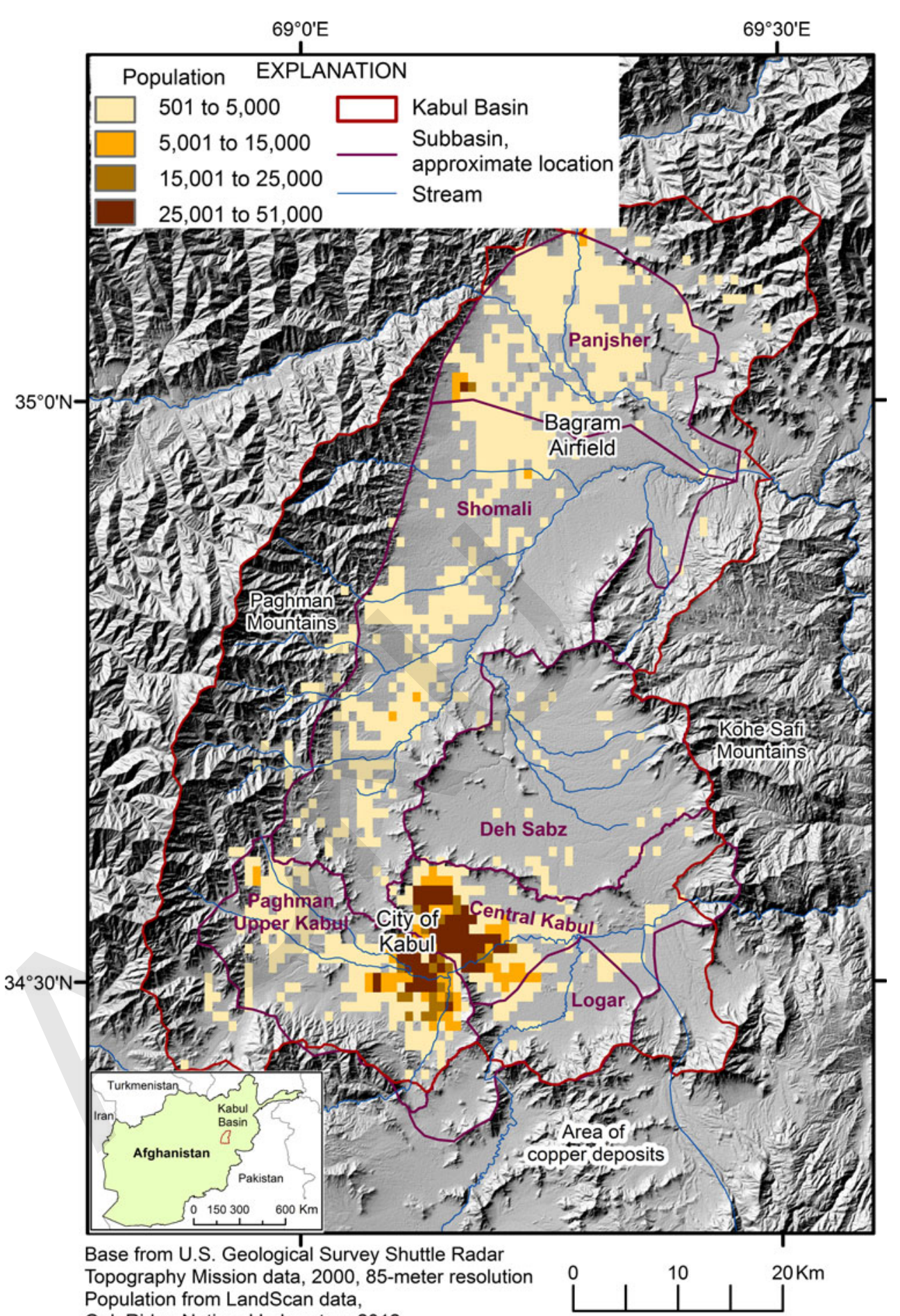

Oak Ridge National Laboratory 2012 mining activities in the region, the sustainability of water resources in the Kabul Basin is of concern to water resource managers (Banks and Soldal 2002; Uhl 2006).

Investigations by the U.S. Department of Defense Task Force for Business and Stability Operations (TFBSO), the U.S. Geological Survey (USGS), and the Afghanistan
Geological Survey (AGS) indicate that copper minerals immediately south of the Kabul Basin (Fig. 1) represent a potential world-class deposit that may provide considerable economic opportunity to Afghanistan (Peters et al. 2011). Water is needed, however, not only to process copper ore, but also to supply the associated population that will be 
needed to accompany a developing mining economy. Understanding the water resources of the Kabul Basin is necessary for operation of the military installations, domestic needs, and commercial activities necessary for the rebuilding of Afghanistan. In this paper, analysis of recently (2008-2012) compiled groundwater-level trend data for the Kabul Basin supports findings of implications for sustainable water use provided by a decision-support model (World Bank 2010) and a groundwater-flow model (Mack et al. 2010).

\subsection{Site description}

The Kabul Basin is the valley formed by the Paghman Mountains to the west and the Kohe Safi Mountains to the east of the city of Kabul (Fig. 1) and extends about $40 \mathrm{~km}$ north of the city. The Kabul Basin can be divided into several subbasins that are separated by bedrock ridges and river drainage divides (Fig. 1). The city of Kabul is primarily in the Central Kabul subbasin, but continued growth has caused the city to expand into the Paghman-Upper Kabul and Logar subbasins. The Paghman-Upper Kabul, Central Kabul, Deh Sabz, and Logar subbasins make up the southern part of the Kabul Basin (Fig. 1).

The central plains of the subbasins are local depositional centers for sediments derived from the surrounding surficial deposits and bedrock outcrops. Alluvial fans have developed on the flanks of the mountains surrounding the subbasins and on the interbasin ridges. Deposits in the central plains (Fig. 2) include alluvium and loess, typically less than 80 meters $(\mathrm{m})$ thick, that overlie semi-consolidated conglomeritic sediments, as much as $1,000 \mathrm{~m}$ thick (Homilius 1969). The primary aquifer in the Kabul Basin is a surficial sedimentary aquifer that occupies the bottom of the basin and subbasins (Fig. 2). The underlying lower semi-consolidated conglomeritic sediments are a secondary, less-used aquifer. Carbon-14 analyses of groundwater by this study and Mack et al. (2010) indicate that groundwater at the base of the upper aquifer is about 1,000 years old and that groundwater at the top of the lower or secondary aquifer (Fig. 2) is 2,800 years old. It is estimated that groundwater deeper in the secondary aquifer is likely many thousands of years old (Mack et al. 2010). The sedimentary and fractured metamorphic and crystalline bedrock of the surrounding mountains and interbasin ridges (Lindsay et al. 2005; Bohannon and Turner 2007; Bohannon 2010) is the least-used aquifer in the Kabul Basin. Studies that have investigated aquifers in the southern Kabul Basin include those by Böckh (1971), Myslil et al. (1982), Broshears et al. (2005), Japan International Cooperation Agency (2007), Lashkaripour and Hussaini (2008), and Houben et al. (2009).
Climate recordkeeping in Afghanistan ceased around 1980, and few climatic data are available for Kabul until 2003 or later. The mean annual precipitation from 1956 to 1983 was estimated to be $312 \mathrm{~mm}$ (mm; World Meteorological Organization 2004). During the late 1990s, there were several years with little or no precipitation, and in 2001, only $175 \mathrm{~mm}$ of precipitation was reported for Kabul (International Water Management Institute 2002). Precipitation measured at the Kabul Airport (Fig. 3) between water years 2004 and 2011 (Afghan water years are September through August) was high in 2005 and 2007, low in 2004 and 2008, and average (about $300 \mathrm{~mm}$ ) in other years. Since 2006, a countrywide climatic monitoring and reporting effort has been active under the Agromet Project, a joint effort by the USGS and Afghanistan's Ministry of Agriculture, Irrigation and Livestock and the Meteorological Authority of the Ministry of Transport (http://afghanistan.cr. usgs.gov/agro). This effort provides not only valuable information for drought monitoring and flood forecasting but maintaining this program will provide long-term climatic data necessary to assess the sustainability of Afghanistan's water supply.

Based on the limited data available, the Kabul Basin has a semi-arid climate where evaporation rates are high relative to annual total precipitation. Net groundwater recharge from direct precipitation in the Kabul Basin is generally near zero on an annual basis. Detailed information on the groundwater flow, including analysis of historical streamflow measurements and isotopic and chemical analyses, was used to develop a groundwater-flow model to assess inflows from river leakage and irrigated areas in the Kabul Basin (Mack et al. 2010). Irrigation provides an increased surface area for water to infiltrate to the underlying aquifer. Although irrigation increases evapotranspiration water losses in the basin, it also captures water that would otherwise flow out of the basin. The Panjshir, Shomali, and Logar subbasins are less-populated, agricultural areas of the Kabul Basin (Fig. 1) that are largely irrigated from traditional surface water diversions. Groundwater-flow simulations of the Kabul Basin accounted for leakage from rivers and from irrigated areas, and incorporated isotopic and chemical analysis of ground and surface water; Mack et al. (2010) concluded that recharge to the aquifer is primarily through leakage from rivers and irrigation.

\subsection{Water use and wells}

Drinking water in the Kabul Basin is generally supplied by shallow (less than 30-m deep) family-owned or community groundwater wells, although there are some municipalsupply wells and associated distribution systems in urban areas, there is no management of groundwater resources. Thousands of shallow wells have been installed by non- 
B
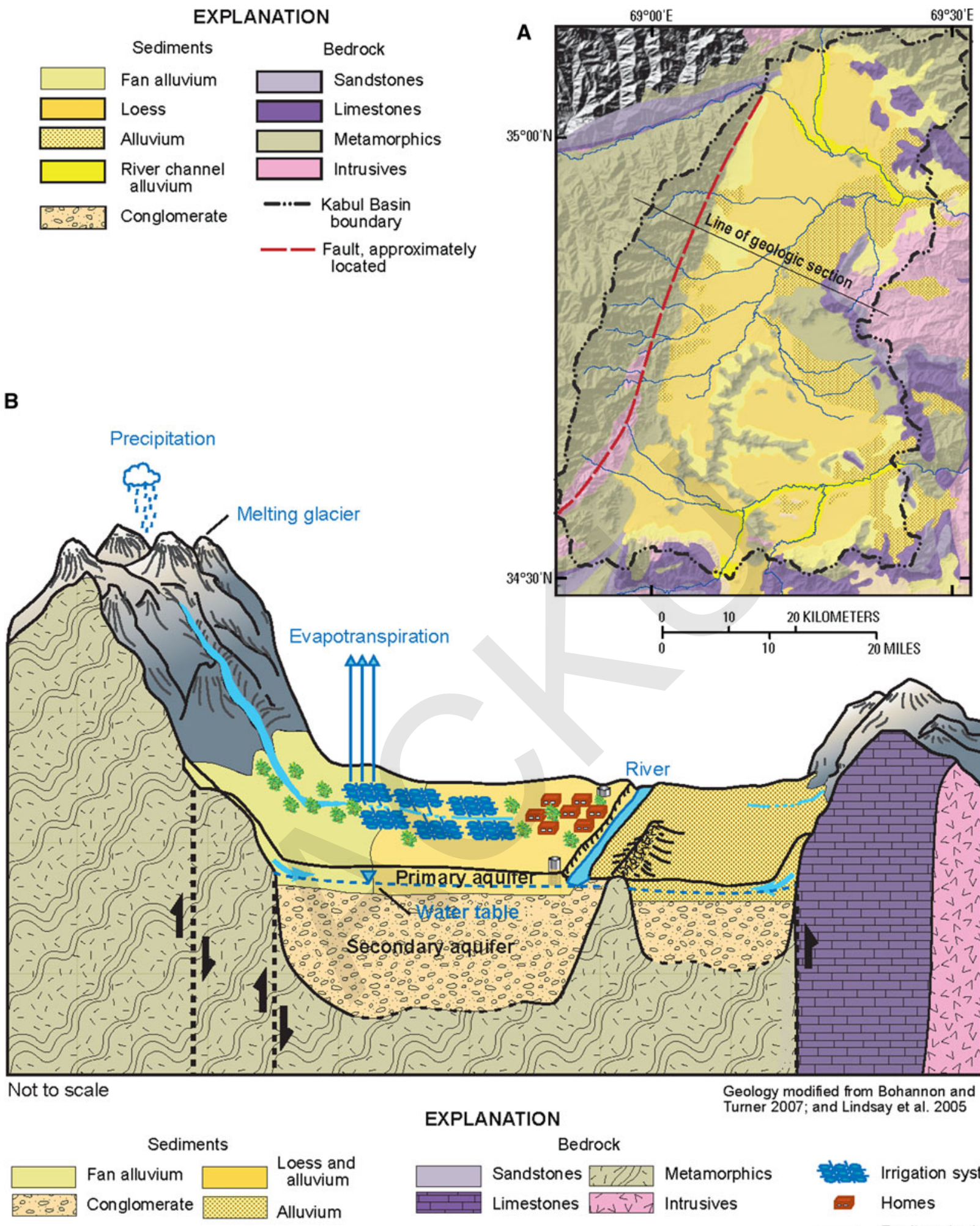

Geology modified from Bohannon and
Turner 2007; and Lindsay et al. 2005
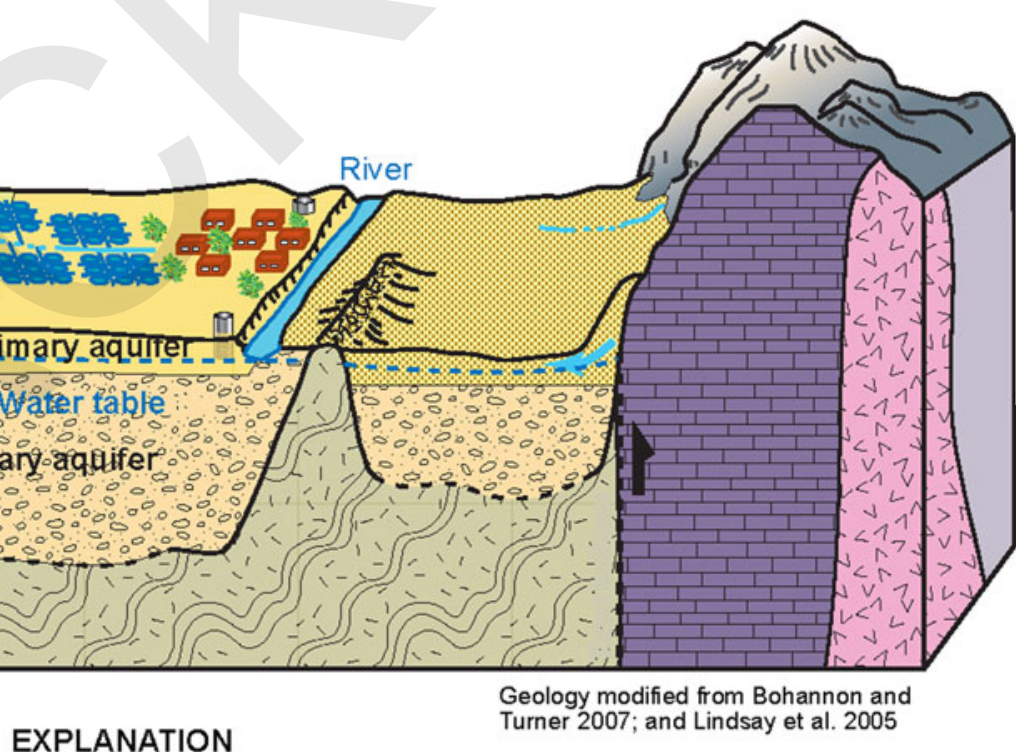


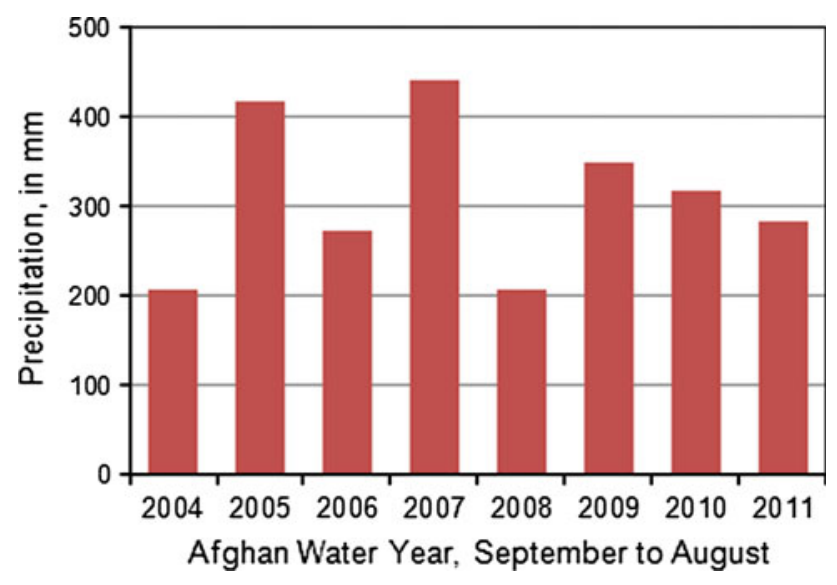

Fig. 3 Annual precipitation at the Kabul Airport, Afghanistan, between 2004 and 2011

median depth of $22 \mathrm{~m}$, were installed by NGOs in the Kabul Basin. About 1,000 of these wells are in three southern subbasins that encompass the city of Kabul (Safi and Vijselaar 2007). Of the wells with a reported status, about $25 \%$ in the city of Kabul and about $20 \%$ in the greater Kabul Basin were reported to be dry or inoperative. The widespread decreases in water levels measured in rural areas of the Kabul Basin in the early and middle 2000s may be more a product of long-term drought than increased water use.

Banks and Soldal (2002) reported groundwater-level decreases of 4-6 $\mathrm{m}$ in Kabul during the drought period of 1998-2002 and as much as $10 \mathrm{~m}$ in some areas. Groundwater-level decreases of 6-7 $\mathrm{m}$ were reported between the 1960s and early 2000s for some parts of the city (Houben et al. 2009). Safi (2005) reports that water levels in the surficial sedimentary aquifer in the city of Kabul had decreased by about 10 m between 1982 and 2005 because of increased water use. The water-level decreases noted by these studies in the city of Kabul, in the early to mid 2000s, likely represent both the widespread effect of drought in the Kabul Basin and locally the effects of increased water use.

There are few population data for Afghanistan and no accurate census data. However, Afghanistan's Central Statistics Office estimated that the city of Kabul had a population of 720,000 in 1978 (Montreal Engineering Company 1978), which has now (2012) increased to about 4 million. A population distribution for the country (Fig. 1) is provided by imagery-derived estimates determined from the LandScan project (Oak Ridge National Laboratory 2012). Although droughts have caused periodic widespread groundwater-level decreases in the Kabul Basin and elsewhere in Afghanistan, continued decreases in the city of Kabul are likely caused by increased groundwater withdrawals for an increasing population. The United Nations Economic and Social Commission for Asia and the Pacific
(UNESCAP 2008) estimated per capita water consumption in Afghanistan to be less than half that of other Central and West Asian countries. With an improving standard of living and a projected population of 9 million by 2057, an estimated sixfold water consumption increase in the Kabul Basin was simulated in the groundwater-flow model described by Mack et al. (2010). The World Bank (2010) in planning scenarios from a decision-support model of the basin also projected increasing per capita water use, associated with an improving standard of living and a population of 6-8 million by 2020 . New water uses associated with potential mining activities along with associated economic growth are expected to contribute to the increased demand for water in the Kabul Basin (World Bank 2010).

\section{Groundwater-level monitoring}

The AGS has operated a monthly water-level monitoring network of about 70 wells (Fig. 4) since 2004 (Akbari et al. 2007). The AGS water-level studies in the Kabul Basin concentrated on wells that ranged in depth from 4.9 to $30 \mathrm{~m}$ that were equipped with hand pumps and electric pumps. The Danish Committee for Aid to Afghan Refugees (DACAAR) has monitored 10 wells in the Kabul Basin for about the same period (Danish Committee for Aid to Afghan Refugees 2011).

Groundwater levels in some parts of the Kabul Basin had decreased substantially as a result of periods of belowaverage precipitation and increased water use during the 2000s (Mack et al. 2010). Yet, in the late 2000s, water levels in rural areas of the Kabul Basin increased in response to increased precipitation (Fig. 3). Currently (2012), the groundwater levels in some areas of the Kabul Basin are increasing (decreasing depth to water), such as at AGS monitoring well 20 in the Shomali subbasin in northern Kabul Basin (Fig. 5). Otherwise, groundwaterlevel decreases (increasing depth to water) in the city appear to be continuing (Fig. 5). At AGS monitoring well 167 in the Central Kabul subbasin (Fig. 4), decreases of about $3 \mathrm{~m}$ were recorded from 2004 to 2007 and about $15 \mathrm{~m}$ from 2008 to 2012 (Fig. 5).

Trends in groundwater levels from 2004 to 2012 in the Kabul Basin were assessed at 66 wells measured by AGS and 10 wells measured by DACAAR. The Seasonal Kendall test (Hirsch and Slack 1984; Helsel et al. 2006) was used to determine whether trends were evident as indicated by a significant slope in groundwater levels over time. The slopes of trends (Fig. 6) indicate where groundwater levels are significantly increasing (negative slope), show no trend (slopes near zero), or groundwater levels are decreasing (positive slope). From 2004 to 2012, 
Fig. 4 The monitoring well network in the Kabul Basin, Afghanistan

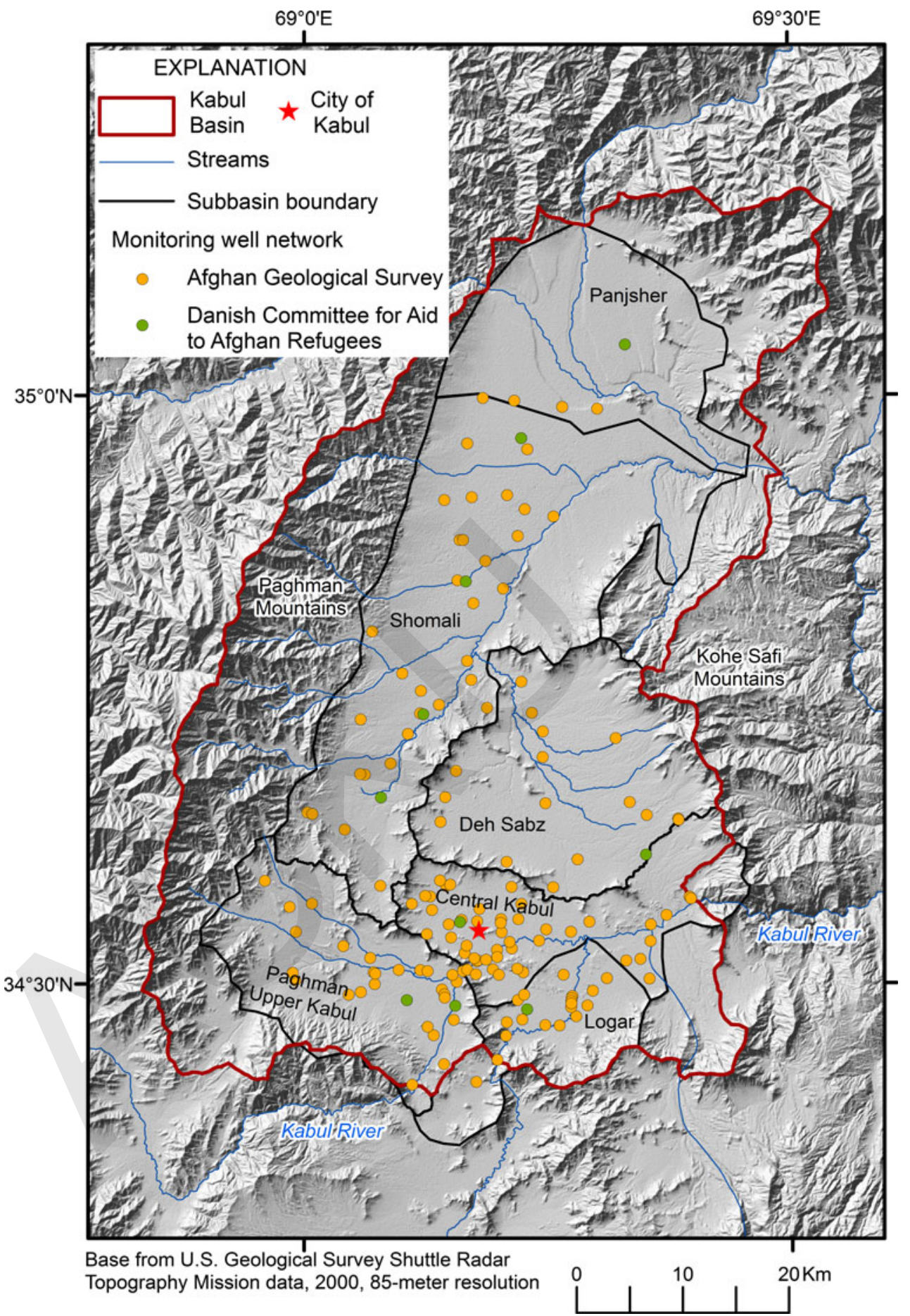

the median rate of groundwater-level increase, detected in 16 of 69 monitoring wells, was $0.31 \mathrm{~m} / \mathrm{yr}$. Groundwaterlevel increases were greater near streams in the northern Kabul Basin. Between 2004 and 2012, the median rate of groundwater-level decrease measured in 19 of 69 monitoring wells was $0.76 \mathrm{~m} / \mathrm{yr}$-about twice the rate of median water-level increase. Figure 6 indicates that groundwater-level decreases are primarily in the city of Kabul. Decreases are greatest farther from recharge sources such as rivers or large mountain fronts.

The trend of groundwater-level decreases in the city of Kabul appears to be greater from 2008 to 2012, the latter half of the period of record (Fig. 5). Changes in the trend in groundwater level with time were assessed at 19 monitoring 


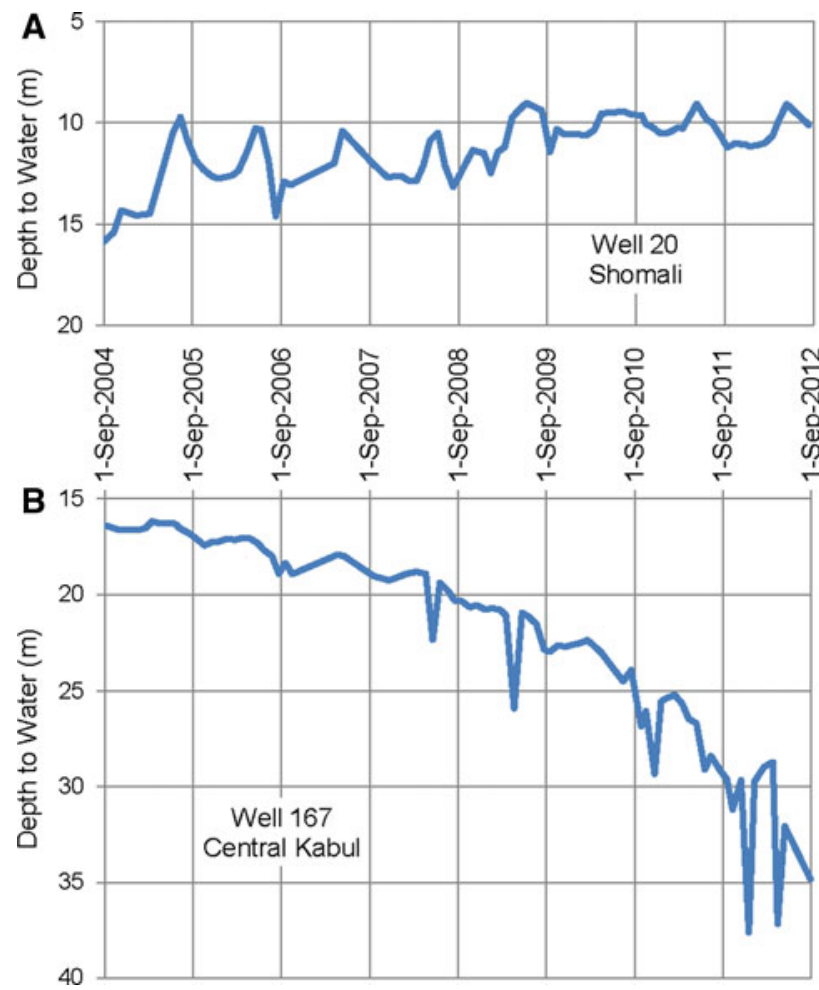

Fig. 5 Monthly depth to water at Afghanistan Geological Survey wells a 20 and b 167 from September 2004 to 2012 in the Kabul Basin, Afghanistan

wells in the city by separating the data for the period of record into two groups: start of record (generally the fall of 2004) to August 2008 and September 2008 to 2012 (Table 1). For the 2004 to 2008 period, most wells (14) indicated no trend, while four wells had an average rate of groundwater-level decrease of $0.7 \mathrm{~m} / \mathrm{yr}$ (with a maximum rate of $0.9 \mathrm{~m} / \mathrm{yr}$ ). Well 208, adjacent to the Kabul River, had a rate of groundwater-level increase of $2 \mathrm{~m} / \mathrm{yr}$ (Fig. 7; Table 1). However, for the 2008-2012 period, all but three wells had a greater rate of groundwater-level decrease (Fig. 7; Table 1). Overall, the rate of groundwater-level decrease became more pronounced between the earlier and later period of record. The average rate of decrease for the 2008-2012 period was $1.5 \mathrm{~m} / \mathrm{yr}$ with rates of decrease of more than $4 \mathrm{~m} / \mathrm{yr}$ in the northwestern area of the city (Fig. 7).

The Central Kabul subbasin area of the Kabul Basin, which contains the main part of the city of Kabul and is densely populated, is removed from the primary sources of recharge in the basin, river and irrigation leakage, and mountain-front recharge, by distance and topography (Fig. 7). Additionally, the unconsolidated sediments in the northern area of the Central Kabul subbasin are isolated from recharge by Kabul River leakage by a conglomerate ridge (between wells 170 and 172 in Fig. 7). All of these factors contribute to the trend of groundwater-level decreases in the city of Kabul.

\section{Groundwater sustainability in the Kabul Basin}

The regional groundwater-level trend in the Kabul Basin, outside the city of Kabul, indicates no change to slight increases in groundwater levels since the drought of the early 2000s. However, groundwater levels in the city of Kabul have decreased considerably since the early 2000s as a result of increasing population and associated groundwater use. Over the past 4 years (2008-2012), the rate of groundwater-level decrease has accelerated in the city of Kabul to more than $4 \mathrm{~m} / \mathrm{yr}$ in some areas. The mean depth of NGO installed community-supply wells in the Kabul Basin is about $22 \mathrm{~m}$, and the mean static (non-pumped) depth to water in such wells is about $12 \mathrm{~m}$. In such wells, this leaves very little available water for pumping or to accommodate seasonal fluctuations in water levels. Although hydrologic, water use, and population data are sparse in the Kabul Basin, the water use by military installations, with an estimated total population of 75,000 in the Kabul Basin, is likely to be small relative to that of the general population of 4 million in the basin. Detailed records for groundwater withdrawals at military installations were not available to this study.

Most of the recharge in the Kabul Basin is from surface water leakage, either by direct infiltration of river water or by infiltration of river water diverted on to irrigated areas. The sustainability of groundwater supplies is greater in northern areas of the Kabul Basin due to higher recharge from surface water leakage from streams and large irrigated areas, and from mountainfront recharge. With the exception of limited recharge from leakage from the Kabul River, most of the city of Kabul is farther from these sources of recharge, which means the potential sustainability of groundwater water supplies in the city is uncertain. The northwestern part of the city of Kabul (Fig. 7), the western part of the Central Kabul subbasin, is particularly susceptible, as conglomerate ridges may form a barrier to groundwater flow in shallow unconsolidated sediments recharged from Kabul River leakage. Military installations in the city of Kabul are primarily south of the conglomerate ridge and may be better connected hydraulically to sources of recharge from the Kabul and Logar Rivers. However, installations in the Central Kabul subbasin north of the conglomerate ridge, such as those at the Kabul International Airport, are in an area that lacks the recharge necessary for sustainability of groundwater supplies, as evidenced from decreased groundwater levels - a condition exacerbated by interference from 
Fig. 6 Groundwater-level trends from 2004 to 2012 in the Kabul Basin, Afghanistan

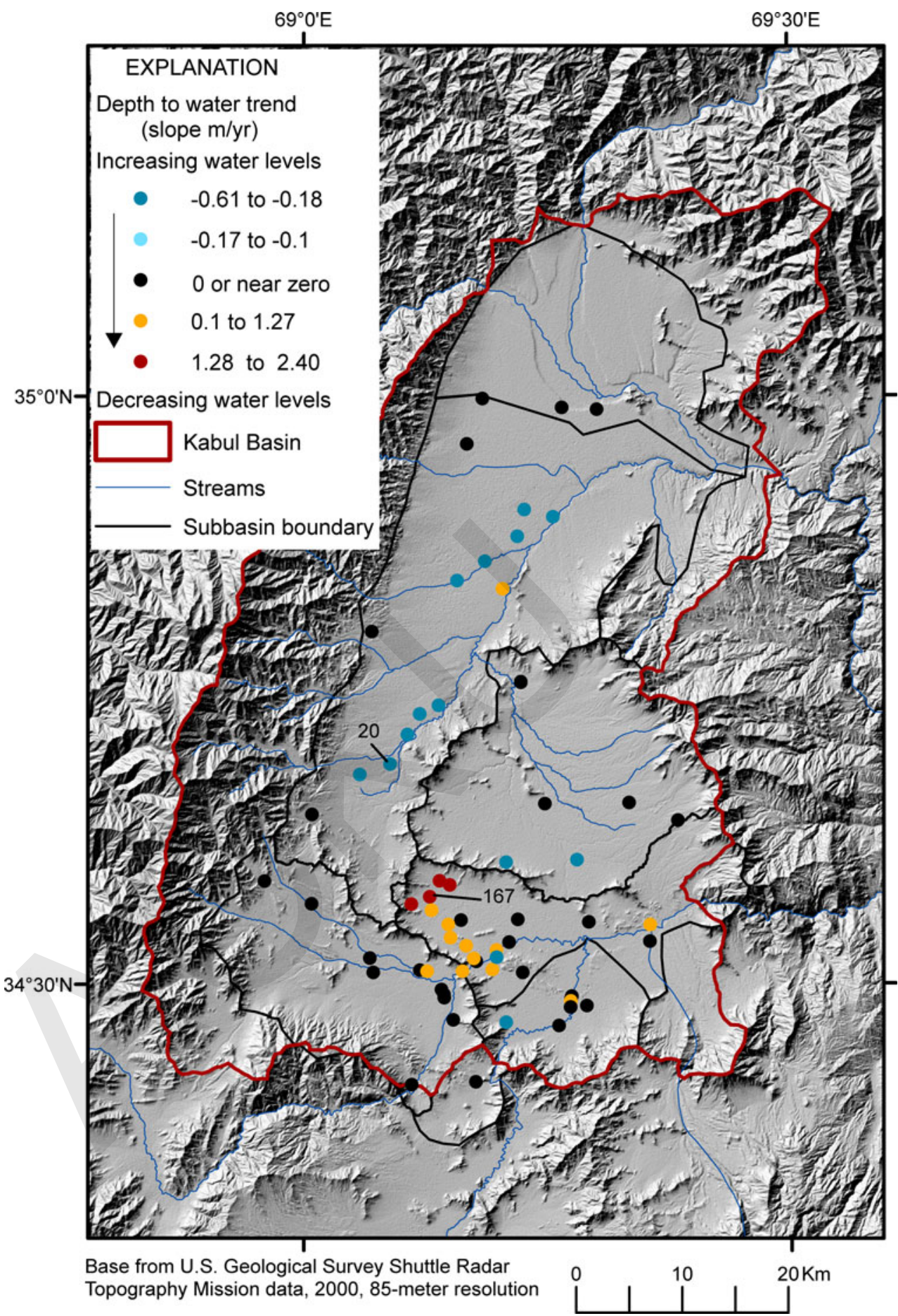

multiple withdrawal wells in close proximity to one another. Groundwater levels can be expected to undergo further decreases without regional water resource management including careful siting of new wells and the evaluation of increased withdrawals.

Based on groundwater-flow simulations of projected increased water use in the city of Kabul, it is estimated that about $40 \%$ of existing wells in the surficial sedimentary aquifer may become inoperable by 2057 (Mack et al. 2010). Decreasing groundwater levels have been reported in the city of Kabul for several decades; however, longterm water-level data are not available to confirm this trend. Although only an 8-year groundwater-level record was available and continued monitoring is needed, analysis 
Table 1 Groundwater-level trends, from 2004 to 2012, at Afghanistan Geological Survey monitoring wells in the city of Kabul, Afghanistan

\begin{tabular}{|c|c|c|c|c|c|c|c|c|c|c|c|c|}
\hline \multirow[b]{2}{*}{$\begin{array}{l}\text { Monitoring } \\
\text { well identifier }\end{array}$} & \multicolumn{4}{|l|}{ 2004-2012 } & \multicolumn{4}{|c|}{2004 to August 2008} & \multicolumn{4}{|c|}{ September 2008-2012 } \\
\hline & $\begin{array}{l}\text { Correlation } \\
\text { coefficient }\end{array}$ & $P$ value & Slope & $\begin{array}{l}\text { Trend } \\
(\mathrm{m} / \mathrm{yr})\end{array}$ & $\begin{array}{l}\text { Correlation } \\
\text { coefficient }\end{array}$ & $P$ value & Slope & $\begin{array}{l}\text { Trend } \\
(\mathrm{m} / \mathrm{yr})\end{array}$ & $\begin{array}{l}\text { Correlation } \\
\text { coefficient }\end{array}$ & $P$ value & Slope & $\begin{array}{l}\text { Trend } \\
(\mathrm{m} / \mathrm{yr})\end{array}$ \\
\hline 2 & 0.95 & 0.00 & 0.79 & 0.79 & 1.00 & 0.00 & 0.47 & 0.47 & 0.86 & 0.00 & 0.64 & 0.64 \\
\hline 64 & 0.45 & 0.00 & 0.33 & 0.33 & -0.52 & 0.07 & -0.18 & $*$ & 0.79 & 0.00 & 1.10 & 1.10 \\
\hline 65 & 0.83 & 0.00 & 1.62 & 1.62 & -0.25 & 0.74 & -0.40 & $*$ & 0.93 & 0.00 & 3.26 & 3.26 \\
\hline 124 & 0.40 & 0.01 & 0.16 & 0.16 & -0.18 & 0.60 & -0.17 & $*$ & 0.57 & 0.02 & 0.56 & 0.56 \\
\hline 127 & 0.63 & 0.00 & 0.00 & 0.00 & -0.07 & 1.00 & -0.02 & $*$ & 0.71 & 0.00 & 0.86 & 0.86 \\
\hline 129 & 0.55 & 0.00 & 0.35 & 0.35 & -0.22 & 0.55 & -0.14 & $*$ & 0.79 & 0.00 & 1.00 & 1.00 \\
\hline 133 & 0.42 & 0.00 & 0.21 & 0.21 & -0.20 & 0.51 & -0.14 & $*$ & 0.79 & 0.00 & 0.79 & 0.79 \\
\hline 153 & -0.16 & 0.30 & -0.28 & $*$ & -0.28 & 0.33 & -0.87 & $*$ & 0.29 & 0.28 & 0.74 & $*$ \\
\hline 157 & 0.24 & 0.11 & 0.16 & $*$ & -0.52 & 0.05 & -0.20 & $*$ & 0.71 & 0.00 & 0.79 & 0.79 \\
\hline 163 & -0.32 & 0.25 & -0.30 & $*$ & -0.52 & 0.07 & -0.38 & $*$ & $* *$ & $* *$ & $* *$ & $* *$ \\
\hline 167 & 1.00 & 0.00 & 1.77 & 1.77 & 1.00 & 0.00 & 0.92 & 0.92 & 1.00 & 0.00 & 3.37 & 3.37 \\
\hline 168 & 0.98 & 0.00 & 1.27 & 1.27 & 0.92 & 0.00 & 0.87 & 0.87 & 1.00 & 0.00 & 1.88 & 1.88 \\
\hline 170 & 0.83 & 0.00 & 1.13 & 1.13 & 0.64 & 0.02 & 0.39 & 0.39 & 0.71 & 0.00 & 1.76 & 1.76 \\
\hline 172 & 0.55 & 0.00 & 0.30 & 0.30 & 0.00 & 1.00 & 0.00 & * & 0.71 & 0.00 & 0.69 & 0.69 \\
\hline 173 & 0.82 & 0.00 & 0.76 & 0.76 & 0.44 & 0.10 & 0.28 & $*$ & 0.93 & 0.00 & 1.37 & 1.37 \\
\hline 208 & -0.47 & 0.00 & -0.61 & -0.61 & -0.89 & 0.00 & -1.94 & -1.94 & -0.07 & 0.88 & -0.12 & $*$ \\
\hline 210 & 0.20 & 0.23 & 0.14 & $*$ & -0.33 & 0.37 & -0.14 & $*$ & 0.61 & 0.01 & 0.46 & 0.46 \\
\hline 219 & 0.65 & 0.00 & 2.40 & 2.40 & 0.44 & 0.10 & 2.26 & $*$ & 0.86 & 0.00 & 4.52 & 4.52 \\
\hline 220 & 0.36 & 0.04 & 1.65 & 1.65 & -0.25 & 0.74 & -1.38 & $*$ & 0.43 & 0.09 & 2.61 & $*$ \\
\hline
\end{tabular}

$m$ meter, $y r$ year, - negative indicates a groundwater-level increase

* Not significant at a $P$ value of 0.05

** Insufficient data to calculate trend

of trends from 2004 to 2012 appears consistent with the regional groundwater model analyses (Fig. 7) and implies that current and increased rates of groundwater withdrawal are not sustainable in the Central Kabul subbasin area of the city of Kabul. Likewise, a World Bank (2010) scoping report on development in the Kabul Basin finds that a combination of new water storage projects (dams) and a conveyance link to groundwater from the Panjsher subbasin would be needed to support population growth and the Aynak mining project. Water balance estimates, based on historical river flows (Mack et al. 2010), indicate that the northern Kabul subbasins (Panjsher and Shomali) have 5 times the total inflows of the southern Kabul basins (Central Kabul, Paghman and Upper Kabul, and Logar), which supports the scoping report plan.

The potential development of mineral resources near the city of Kabul will likely increase the demand for water resources in the city as well; this study identifies settings such as small basins isolated from recharge sources, where groundwater levels may be most affected by withdrawals.
Groundwater in the lower semi-consolidated aquifer may support additional withdrawals to help meet future water needs, and groundwater-flow simulation can be a useful tool for assessing the sustainability of groundwater management options (Mack et al. 2010). Assessment of the sustainability of groundwater at military installations in the Kabul Basin needs careful evaluation of the placement and use of new withdrawal wells-particularly with respect to existing water supplies for the surrounding communities. Sustainable use of water in the Kabul Basin will likely require regional management strategies that include consideration of the use of both surface water storage and groundwater resources. Continued climate and groundwater-level monitoring, and establishment of a surface water monitoring network, are needed for assessment of water resources sustainability and informed resource decision-making. However, given current (2012) security issues in Afghanistan, resource monitoring activities are difficult and management may be equally challenging. 
Fig. 7 Groundwater-level trends, decrease in meters per year, from September 2008 to 2012, and simulated groundwater drawdown with a projected sixfold population increase in the city of Kabul, Afghanistan

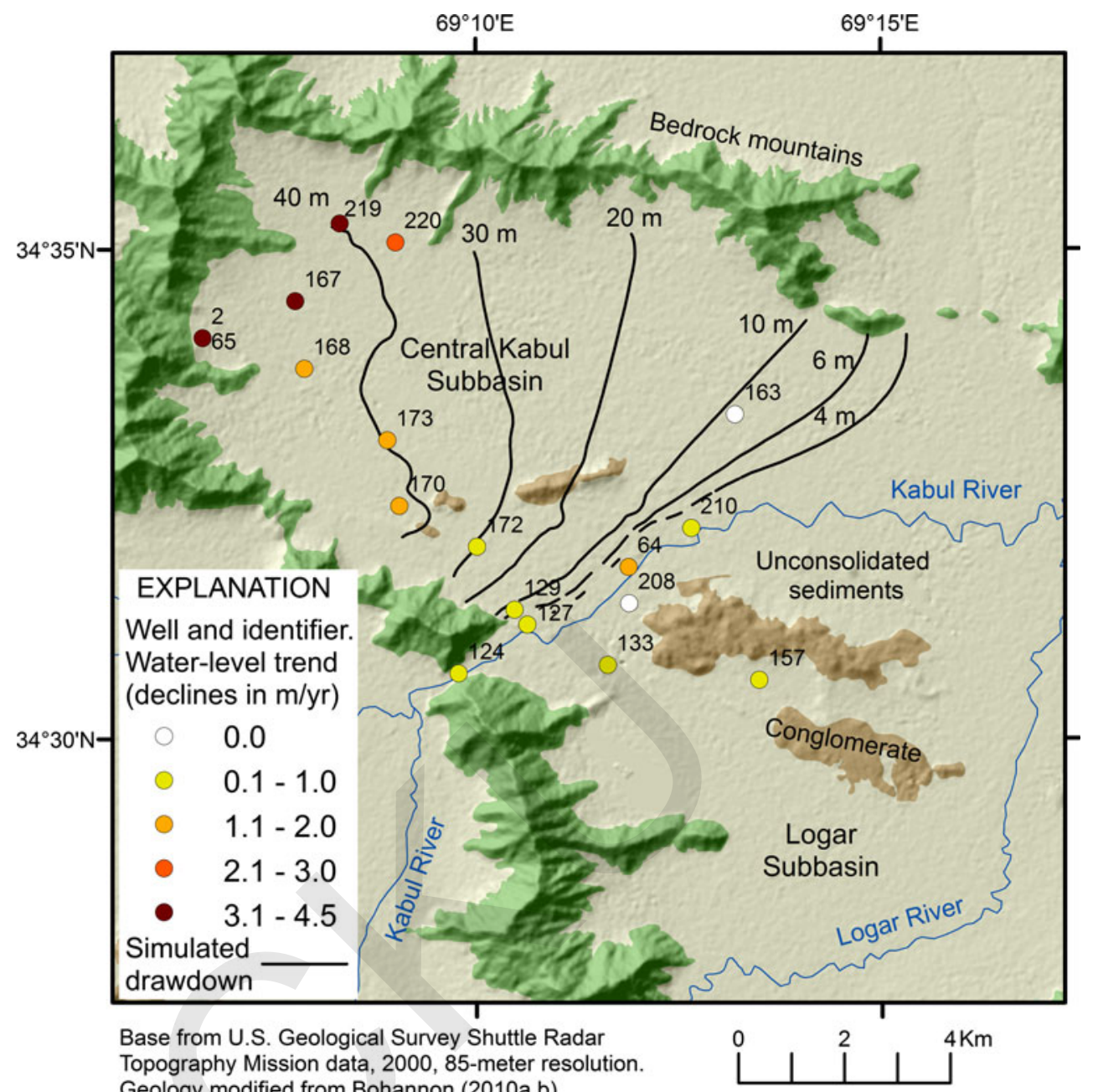

Topography Mission data, 2000, 85-meter resolution. Geology modified from Bohannon (2010a,b)
Open Access This article is distributed under the terms of the Creative Commons Attribution License which permits any use, distribution, and reproduction in any medium, provided the original author(s) and the source are credited.

\section{References}

Akbari MA, Tahir M, Litke DW, Chornack MP (2007) Groundwater levels in the Kabul Basin, Afghanistan, 2004-07. U.S. Geological Survey open-file report 2007-1294, 46 pp

Banks D, Soldal O (2002) Towards a policy for sustainable use of groundwater by non-governmental organizations in Afghanistan. Hydrogeol J 10:377-392

Böckh EG (1971) Report on the groundwater resources of the city of Kabul. Bundesanstalt für Geowissenschaften und Rohstoffe [unpublished] file number 0021016, $43 \mathrm{pp}$

Bohannon RG (2010) Geologic and topographic maps of the Kabul North $30^{\prime} \times 60^{\prime}$ quadrangle, Afghanistan. U.S. Geological Survey Scientific Investigations Map 3120, 34 pp, 2 map sheets, scale $1: 100,000$

Bohannon RG, Turner KJ (2007) Geologic map of quadrangle 3468, Chak Wardak-Syahgerd (509) and Kabul (510) quadrangles, Afghanistan. U.S. Geological Survey open-file report 2005-1107-A, 1 sheet
Broshears RE, Akbari MA, Chornack MP, Mueller DK, Ruddy BC (2005) Inventory of groundwater resources in the Kabul Basin, Afghanistan. U.S. Geological Survey scientific investigations report 2005-5090, $34 \mathrm{pp}$

Danish Committee for Aid to Afghan Refugees (DACAAR) (2011) Update on "National groundwater monitoring wells network activities in Afghanistan" from July 2007 to December 2010. DACAAR, Kabul, 23 pp

Gellasch CA (2012) Hydrogeological support to United States military operations, 1917-2010. In: Rose EPF, Mather JD (eds) Military aspects of hydrogeology. Geological Society Special Publication 362, pp 223-239

Helsel DR, Mueller DK, Slack JR (2006) Computer program for the Kendall family of trend tests. U.S. Geological Survey Scientific Investigations Report 2005-5275, 4 pp

Hirsch RM, Slack JR (1984) A nonparametric trend test for seasonal data with serial dependence. Water Resour Res 20:727-732

Homilius J (1969) Geoelectrical investigations in east Afghanistan. Geophys Prospect 17(4):468-487

Houben G, Niard N, Tunnermeier T, Himmelsbach T (2009) Hydrogeology of the Kabul Basin (Afghanistan), part I: Aquifer and hydrology. Hydrogeo. J. 17:665-677

International Water Management Institute (2002) Current drought situation in Afghanistan. http://www.iwmi.cgiar.org/droughtasses sment/files/pdf/Drought2000inAfghanistan.pdf. Accessed February 28,2005 
Japan International Cooperation Agency (2007) The study on groundwater resources potential in Kabul Basin, in the Islamic Republic of Afghanistan. Sanyu Consultants, Inc., Kabul, 20 pp

Lashkaripour GR, Hussaini SA (2008) Water resources management in Kabul River basin, eastern Afghanistan. Environmentalist 28(3):253-260

Lindsay CR, Snee LW, Bohannon RR, Wahl RR, Sawyer DA (2005) Geologic map of quadrangle 3568, Polekhomri (503) and Charikar (504) quadrangles, Afghanistan. U.S. Geological Survey open-file report 2005-1101-A

Mack TJ, Akbari MA, Ashoor MH, Chornack MP, Coplen TB, Emerson DG, Hubbard BE, Litke DW, Michel RL, Plummer LN, Rezai MT, Senay GB, Verdin JP, Verstraeten IM (2010) Conceptual model of water resources in the Kabul Basin, Afghanistan. U.S. Geological Survey scientific investigations report 2009-5262, 240 pp. http://pubs.usgs.gov/sir/2009/5262

Montreal Engineering Company (1978) Kabul River Valley development project, master plan report, book one. Montreal Engineering Company, Montreal

Myslil V, Eqrar MN, Hafisi M (1982) Hydrogeology of Kabul Basin (translated from Russian). United Nations Children's Fund and the Ministry of Water and Power, Democratic Republic of Afghanistan, $47 \mathrm{pp}$

North Atlantic Treaty Organization (NATO) (2013) International Security Assistance Force (ISAF): key facts and figures. NATO, http://www.nato.int/isaf/docu/epub/pdf/placemat.pdf. Accessed 24 May 2013

Oak Ridge National Laboratory (2012) LandScan global population database 2011. http://www.ornl.gov/sci/landscan/. Accessed 1 Nov 2012
Peters SG, King TVV, Mack TJ, Chornack MP (eds) (2011) Summaries of important areas for mineral investment and production opportunities of nonfuel minerals in Afghanistan. U.S. Geological Survey open-file report 2011-1204, 1810 pp, appendices. http://pubs.usgs.gov/of/2011/1204/. Accessed 24 May 2013

Safi H (2005) Report on groundwater balance deficiency and contamination in Kabul City. DACAAR Kabul, Afghanistan, 7 $\mathrm{pp}$

Safi H, Vijselaar L (2007) Groundwater monitoring, evaluation of groundwater data. Danish Committee for Aid to Afghan Refugees (DACAAR), Kabul

Uhl VW (2006) Afghanistan-an overview of groundwater resources and challenges. Ground Water 44(5):626-627

United Nations, Department of Economic and Social Affairs, Population Division (2011) World population prospects: the 2010 revision. United Nations, Department of Economic and Social Affairs, CD-ROM edition

United Nations Economic and Social Commission for Asia and the Pacific (UNESCAP) (2008) Statistical yearbook for Asia and the Pacific 2007. UNESCAP, http://www.unescap.org/stat/data/ syb2007/ESCAP-SYB2007.pdf. Accessed 5 Sept 2012

World Bank (2010) Afghanistan, scoping strategic options for development of the Kabul River Basin, a multisectoral decision support system approach. The World Bank, $130 \mathrm{pp}$

World Meteorological Organization (2004) Weather information for Kabul. World Meteorological Organization, http://www.world weather.org/115/c00219.htm. Accessed 10 Dec 2007 